\title{
Pendampingan Pengisian Data Aplikasi InaRisk Dasawisma Untuk Pencegahan Covid-19 Berbasis Keluarga di Kabupaten Sumenep
}

\author{
Anik Anekawati ${ }^{1)}$, Eko Mulyadi ${ }^{2)}$, Roos Yuliastina ${ }^{3)}$ \\ ${ }^{1)}$ Fakultas Keguruan dan Ilmu Pendidikan, Universitas Wiraraja, ${ }^{2)}$ Fakultas Ilmu Kesehatan, \\ Universitas Wiraraja, ${ }^{3)}$ Fakultas Ilmu Sosial dan Ilmu Politik, Universitas Wiraraja \\ E-mail : anik@wiraraja.ac.id
}

\begin{abstract}
Abstrak
Permasalahan mitra yaitu pelayanaan bidang akademikterkendala dengan adanya pandemi Covid-19 khususnya dharma Pengabdian Kepada Masyarakat (PKM) dan KKN. Solusi yang ditawarkan pendampingan peserta KKN secara daring menjadi relawan informasi dengan memanfaatkan aplikasi InaRisk milik BNPB pusat. Permasalahan lain adalah aplikasi InaRisk milik pihak lain, sehingg mitra dan pelaksana pengabdi tidak mendapatkan data hasil isian aplikasi InaRisk tersebut. Solusi yang ditawarkan adalah mengembangkan aplikasi berbasis web dengan indikator sama dengan di aplikasi InaRisk. Metode pelaksanan merupakan satu kesatuan dalam pendampingan dan sosialiasi pengisian data tingkat risiko penyebaran Covid-19 melalui pendataan terhadap keluarga inti dan dasawisma (Inarisk Keluarga). Jumlah responden yang berhasil dikumpulkan Inarisk Keluarga sebanyak 7.380. Berikut dimensi dari Inarisk Desawisma di Kabupaten Sumenep dengan persentase indiktor tertinggi:pengetahuan tentang Covid-19 (Keluarga saya mengetahui tentang Covid-19: 97,737\%), lingkungan rumah (keluarga saya tinggal di rumah dengan pencahayaan sinar matahari langsung: 93,509\%), kondisi tempat tinggal (tempat tinggal keluarga saya memiliki sumber air bersih: 97,182\%), perilaku/kebiasaan(keluarga saya menyediakan : tissue basah/antiseptic, masker, sabun antiseptic dan disinfektan bagi keluarga di rumah: 73,293\%), rencana keluarga(keluarga saya memiliki aturan dan kesepakatan dalam menerapkan pola hidup bersih dan sehat (phbs) di rumah: 83,509\%), kapasitas keluarga(anggota keluarga tidak ada yang mempunyai penyakit : jantung/diabetes/gangguan pernafasan kronik: 74,038\%).
\end{abstract}

Kata kunci :Covid-19, Dasawisma, Inarisk

\section{Pendahuluan}

UU No. 20 Tahun 2003 tentang Sistem

Pendidikan Nasional, pada Pasal 20 ayat 2 menyatakan: "Perguruan Tinggi berkewajiban menyelenggarakan pendidikan, penelitian dan pengabdian masyarakat". Pada Pasal 24 ayat 2 disebutkan: "Perguruan tinggi memiliki otonomi untuk mengelola sendiri lembaganya sebagai pusat penyelenggaraan pendidikan tinggi, penelitian ilmiah, dan pengabdian masyarakat". Pengertian Pengabdian kepada Masyarakat menurut UU RI Nomor 12 tahun 2012 adalah kegiatan sivitas akademika yang memanfaatkan Ilmu Pengetahuan dan Teknologi untuk memajukan kesejahteraan masyarakat dan mencerdaskan kehidupan bangsa, sehingga wajib bagi dosen dan mahasiswa melaksanakan dharma pengabdian kepada masyarakat. 
2. Pelaksanaan Tridharma Perguruan Tinggi, terutama kegaiatan pengabdian dan $\mathrm{KKN}$ bagi mahasiswa pada saat ini terkendala dengan adanya pandemi Covid-19, yang sudah dinyatakan sebagai bencana nasional dengan tingkat risiko penyebaran yang tinggi dan cenderung masif. Pandemi Covid-19 cenderung menimbulkan permasalahan sosial ekonomi yang cukup kompleks, sehingga perlu dilakukan langkahlangkah penanggulangan terpadu yang melibatkan semua pihak dan atau pentahelix termasuk keterlibatan perguruan tinggi.

3. Banyak cara keterlibatan sivitas akademika dalam melakukan pencegahan dan penanggulangan Covid19 ini. Salah satu usaha yang dilakukan adalah pendataan keluarga dan tetangga terdekat (dasawisma). Keluarga sebagai unit sosial terkecil dari masyarakat merupakan pertahanan pertama dan utama dalam pencegahan penularan COVID-19. Terlebih pada saat status lockdown diberlakukan, maka anggota keluarga menjadi berkumpul kembali. Kondisi ini perlu dimanfaatkan untuk meningkatkan kualitas peran dan fungsi keluarga dalam menanggulani penyebaran Covid-19. Oktowaty et al. (2018) menemukan korelasi keterlibatan peran dan fungsi keluarga terhadap peningkatan kualitas hidup anggota keluarga yang terkena penyakit kronis. Santika (2020), mengkaji mengoptimalisasi peran keluarga dalam menghadapi persoalan Covid-19 dengan mendisiplinkan perilaku anggotanya, mengedukasi anggota keluarga untuk mematuhi protokol kesehatan, mempersiapkan dan memenuhi kebutuhan hidup anggotanya, dan memelihara kesehatan mental anggotanya.

4. Friedman (2010), menyebutkan ada 5 pokok tugas keluarga dalam bidang kesehatan sebagai berikut: (a) Mengenal masalah kesehatan keluarga; (b) Membuat keputusan tindakan yang tepat; (c) Memberi perawatan pada anggota keluarga yang sakit; (d) Mempertahankan atau mengusahakan suasana rumah yang sehat; (e) Menggunakan fasilitas pelayanan kesehatan yang ada di masyarakat. Peran dan fungsi keluarga dalam mengetahui informasi dan penanggulangan COVID-19 masih sebatas kajian literatur. Hal ini menunjukkan informasi penyebaran COVID-19 berbasis keluarga masih sangat sedikit. Oleh karena itu dibutuhkan pendampingan pengisian 
data penyebaran Covid-19 melalui aplikasi InaRisk.

5. InaRisk adalah suatu aplikasi yang memuat informasi tentang ancaman bencana, kerentanan (populasi, kerugian fisik, ekonomi, dan lingkungan), kapasitas dan resiko bencana (Amila et al. 2021). Pengabdi menawarkan pendampingan pengisian aplikasi InaRisk karena pada dasarnya aplikasi ini sudah dikembangkan oleh BNPB sejak tahun 2014 untuk mengetahui tingkat risiko personal dan atau publik terhadap ancaman atau potensi bencana (alam) dengan prinsip 'how risky of your place' dalam masa pandemi Covid19, fiturnya ditambah dengan assessmen atau penilaian tentang Covid-19 yang terdiri akses personal/ individu, keluarga, dan desa dalam upaya sosialisasi, edukasi dan mitigasi penanganan Covid-19. Aplikasi ini dibangun untuk menggugah kesadaran warga masyarakat atas ancaman bencana yang ada disekitarnya agar dapat melakukan upaya antisipasi dan mitigasi secara mandiri/ swadaya (BNPB, 2020). Pengisian data InaRisk dilakukan dengan menjawab pertanyaan Ya/Tidak sesuai dengan kategori yang tersedia yaitu, pribadi, keluarga, dan desa. Hasil akhir data yang diperoleh maka terdapat tiga tingkatan resiko terdiri dari tingkat rendah, sedang, atau tinggi (Amila et al. 2021).

6. Rekam jejak data hasil input peserta pendampingan menggunakan aplikasi Inarisk BNPB dan juga melalui sistem informasi berbasis web. Pendataan dan pemetaan data yang dilakukan oleh mahasiswa peserta KKN Universitas Wiraraja Tahun tahun Akademik 2019 2020

7. Pendataan ini memerlukan pendampingan dengan tujuan agar mahasiswa dalam rangka pengisian data tingkat risiko personal terhadap pandemi Covid-19 ini adalah: (a). Memberikan sosialisasi kepada warga masyarakat tentang pentingnya self assesment (penilaian mandiri) melalui aplikasi InaRISK (personal) terkait dengan akses data dan informasi penanganan COVID-19 yang saat ini telah dan sedang dilakukan oleh BNPB; (b). Melakukan edukasi kepada warga masyarakat tentang upaya pencegahan yang perlu dan penting untuk dilakukan agar dapat mereduksi penyebaran COVID-19 di lingkungan sekitar, melalui aplikasi InaRISK (personal); (c). Mendorong upaya mitigasi warga masyarakat agar mampu melakukan tindakan antisipatif, protektif dan 
adaptif terkait dengan ancaman COVID19 agar seminimal mungkin tidak berisiko tertular. Pengisian penilaian personel, keluarga, dan desawisma dapat membantu pemerintah dalam melakukan pemantauan terhadap capaian peningkatan atau penurunan indeks resiko bencana di Indonesia (Izzani, 2020)

\section{Metode Pelaksanaan}

$$
\text { Metode pelaksanaan kegiatan }
$$
pendampingan pengisian aplikasi Inarisk ini dilakukan melalui beberapa tahapan:

a. Koordinasi dengan Badan Nasional Penanggulangan Bencana (BNPB) pusat;

b. Membuat materi petunjuk pengisian aplikasi Inarisk keluarga;

c. Pembekalan kepada mahasiswa cara pengisian aplikasi Inarisk keluarga dilakukan secara daring melalui zoom meeting;

d. Mengembangkan aplikasi InaRisk berbasis web;

e. Pendampingan kepada mahasiswa sebagai relawan informasi dalam mengisikan data tingkat risiko penyebaran pandemi Covid 19 selama 1 bulan;

f. Pendataan terhadap keluarga initi dan dasawisma / 10 keluargatetangga terdekat (Inarisk Keluarga); g. Pendataan melalui aplikasi milik BNPB pusat dan aplikasi web KKN Universitas Wiraraja;

h. Pendataan menggunakan protokol kesehatan yang ketat jika harus bertemu partisipan atau dilakukan melalui telepon;

i. Evaluasi

\section{Hasil dan Pembahasan}

Jumlah responden yang berhasil dikumpulkan sebanyak 7.380 data keluarga terdiri dari 7.243 di Kabupaten Sumenep dan 137 di luar Kabupaten Sumenep. Peserta KKN wajib mengisi kuisioner di aplikasi InaRisk, anggota keluarga inti dan bisa ditambahkan tetangga atau saudara terdekat.

Berikut klasifikasi responden berdasarkan jenis kelamin, pekerjaan, usia, dan sebaran data berdasarkan kecamatan.

\section{a. Klasifikasi Responden Berdasarkan Jenis Kelamin}

Berikut merupakan grafik klasifikasi responden berdasarkan jenis kelamin.

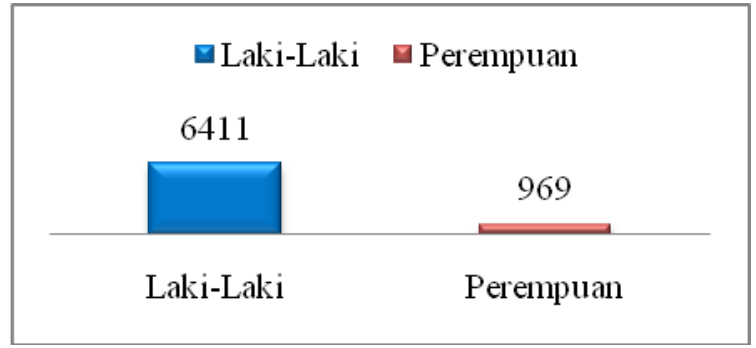


Gambar 1. Responden Berdasarkan Jenis

Kelamin

Gambar di atas menunjukkan bahwa jumlah responden laki-laki (6411) lebih banyak dari pada responden perempuan (969).

b. Klasifikasi Responden Berdasarkan

\section{Pekerjaan}

Berikut merupakan grafik klasifikasi responden berdasarkan pekerjaan.

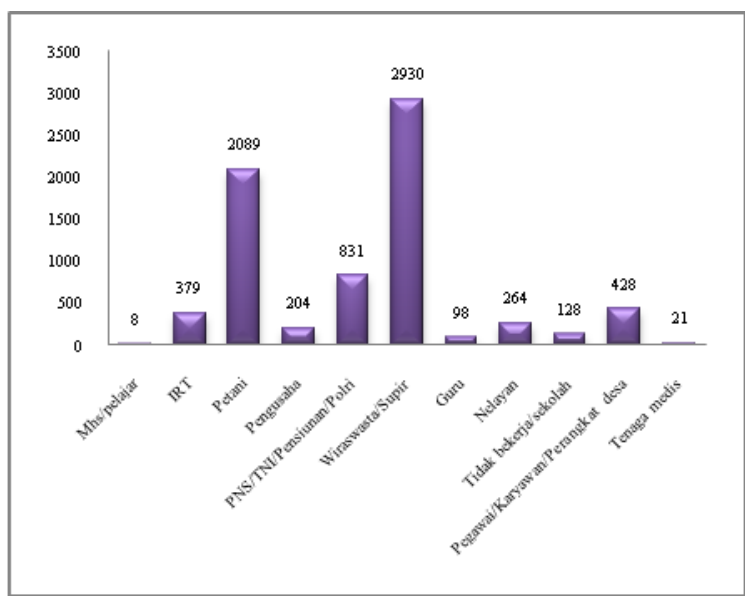

Gambar 2. Responden Berdasarkan Jenis

\section{Pekerjaan}

Gambar di atas menunjukkan bahwa jumlah mayoritas responden berprofesi sebagai wiraswasta atau supir yakni sebanyak 2930orang. Kemudian disusul petanisebanyak 2089 dan PNS/TNI/Pensiunan/Polri 831 orang. Jumlah paling sedikit yakni Mahasiswa/Pelajar sebanyak 8 orang.

\section{c. Klasifikasi Responden Berdasarkan} Usia
Berikut merupakan grafik klasifikasi responden berdasarkan usia.

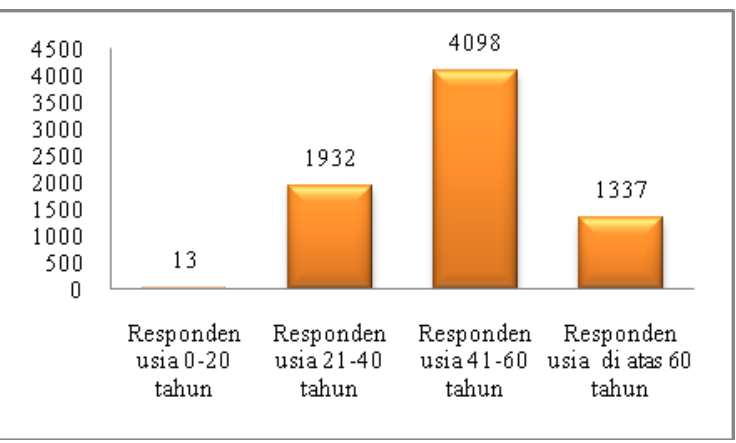

Gambar 3. Responden Berdasarkan Jenis

$$
\text { Usia }
$$

Gambar 3 menunjukkan bahwa usia responden tertinggi adalah usia 41-60 tahun sebanyak 4098 orang. Sedangkan terendah pada usia di atas 0-20 tahun sebanyak 13 orang.

\section{d. Klasifikasi Responden Berdasarkan Kecamatan}

Berikut merupakan grafik klasifikasi responden berdasarkan Kecamatan.

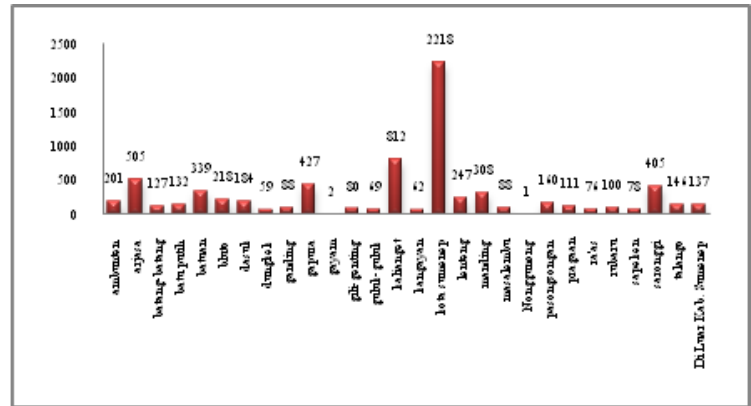

Gambar 4. Responden Berdasarkan Jenis

\section{Kecamatan}

Gambar 4 menunjukkan bahwa jumlah responden terbanyak berasal dari 
Kecamatan Kota Sumenep yakni sebanyak 2218 orang. Sedangkan terendah pada Kecamatan Nonggunong sebanyak 1 orang.

e. Klasifikasi

\section{IndikatorInaRiskDesawisma}

Berikut merupakan persentase dari indikator Inariks seluruh kecamatan yang ada di Sumenep untuk beberapa pertanyaan yang di jawabYa/Tidak oleh responden.

Tabel 1. Persentase Indikator Pengetahuan Tentang Covid-19

PENGETAHUAN
TENTANG COVID-19

\begin{tabular}{lc}
\hline $\begin{array}{l}\text { Keluarga saya mengetahui } \\
\text { tentang COVID-19/Corona. }\end{array}$ & $97,737 \%$ \\
\hline $\begin{array}{l}\text { Keluarga saya mengetahui } \\
\text { penyebab COVID-19/Corona }\end{array}$ & $90.894 \%$ \\
\hline $\begin{array}{l}\text { Keluarga saya mengetahui } \\
\text { dampak dari COVID- }\end{array}$ & $92,168 \%$ \\
19/Corona & \\
\hline $\begin{array}{l}\text { Keluarga saya mengetahui } \\
\text { bagaimana mencegah } \\
\text { penyebaran COVID- } \\
\text { 19/Corona }\end{array}$ & $94,607 \%$ \\
\hline
\end{tabular}

Tabel 2. Persentase Indikator Lingkungan Rumah

\section{LINGKUNGAN RUMAH PERSENTASE}

Keluarga saya tinggal di

kawasan yang tidak padat

$66,165 \%$

penduduk

Keluarga saya tinggal jauh

$61,802 \%$ dengan fasilitas umum

(seperti : pasar, terminal,

stasiun, tempat ibadah)

Keluarga saya tinggal di

rumah dengan pencahayaan

$93,509 \%$

sinar matahari langsung

Tabel 3. Persentase Indikator Kondisi Tempat Tinggal (Rumah)

\section{KONDISI TEMPAT TINGGAL (RUMAH) \\ PERSENTASE}

Tempat tinggal keluarga saya memiliki sumber air bersih $97,182 \%$

Tempat tinggal keluarga saya memiliki MCK (Mandi, Cuci, $92,751 \%$ Kakus)

Setiap anggota keluarga memiliki kamar sendiri

$86,694 \%$

\section{memiliki kamar sendiri}

Tabel 4. Persentase Indikator Perilaku /Kebiasaan

\section{PERILAKU/KEBIASAAN PERSENTASE}

Anggota keluarga memakai masker pada saat berkumpul dengan orang lain Anggota keluarga menjaga jarak 1,5 meter dengan orang lain ketika : belanja, bekerja, belajar, ibadah

\section{Keluarga saya memasang}

hand sanitizer/sabun cuci

tangan di depan pintu masuk,

untuk bersihkan tangan 
Jurnal Abdiraja

ISSN : 2621-9379 (Online)

Volume 4, Nomor 2, September 2021

sebelum pegang gagang

(handle) pintu masuk rumah

Keluarga saya menyediakan :

tissue basah/antiseptic,

masker, sabun antiseptic dan

$73,293 \%$

disinfektan bagi keluarga di

rumah

Tabel 5. Persentase Indikator Rencana Keluarga

\begin{tabular}{lc}
\hline \multicolumn{1}{c}{ RENCANA } & PERSENTASE \\
\hline KngUARGA & \\
mengurangi aktivitas di luar & $76,369 \%$ \\
rumah & \\
\hline Keluarga saya memiliki & \\
aturan dan kesepakatan & $83,509 \%$ \\
dalam menerapkan Pola & \\
hidup Bersih dan Sehat & \\
(PHBS) di rumah & \\
\hline Keluarga saya memiliki & \\
daftar nomor telepon \\
penting (Polisi, Rumah \\
Sakit, Ketua RT/RW) \\
\hline
\end{tabular}

Tabel 6. Persentase Indikator Kapasitas Keluarga

\section{KAPASITAS KELUARGA \\ PERSENTASE}

Keluarga saya tidak

bergantung pada

$55,894 \%$

penghasilan harian

Anggota keluarga tidak

$63,496 \%$ ada yang masuk dalam

kelompok rentan (dibawah

5 tahun atau diatas 65

tahun)

Anggota keluarga tidak
ada yang mempunyai
penyakit :
jantung/diabetes/gangguan
pernafasan kronik
Keluarga saya sudah
menyediakan
perlengkapan P3K, obat-
obatan dan vitamin

Dimensi dari Inarisk Desawisma di Kabupaten Sumenep dengan persentase indiktor tertinggi: pengetahuan tentang Covid-19 (Keluarga saya mengetahui tentang Covid-19: 97,737\%), lingkungan rumah (keluarga saya tinggal di rumah dengan pencahayaan sinar matahari langsung: 93,509\%), kondisi tempat tinggal (tempat tinggal keluarga saya memiliki sumber air bersih: 97,182\%), perilaku/kebiasaan (keluarga saya menyediakan : tissue basah/antiseptic, masker, sabun antiseptic dan disinfektan bagi keluarga di rumah: 73,293\%), rencana keluarga (keluarga saya memiliki aturan dan kesepakatan dalam menerapkan pola hidup bersih dan sehat (phbs) di rumah: 83,509\%), kapasitas keluarga (anggota keluarga tidak ada yang mempunyai penyakit : 
jantung/diabetes/gangguan

pernafasan

kronik: 74,038\%).

Pada indikator tentang perilaku/kebiasaan

keluarga di Sumenep dengan pertanyaan "Keluarga saya memasang hand sanitizer/sabun cuci tangan di depan pintu masuk, untuk bersihkan tangan sebelum pegang gagang (handle) pintu masuk rumah" memperoleh nilai $47,507 \%$ artinya keluarga di beberapa Kecamatan di Kabupaten Sumenep tidak memasang hand sanitizer dan tidak menyediakan tempat cuci tangan di depan rumah.

\section{Simpulan}

Kesimpulan dari pemetaan pendampingan pengisian data menggunakan aplikasi InaRisk dasawisma untuk pencegahan Covid-19 di Kabupaten Sumenep dan sekitarnya diperoleh bahwa pendampingan berhasil mengumpulkan data sebanyak 7.380 data keluarga terdiri dari 7.243 di Kabupaten Sumenep dan 137 di luar Kabupaten Sumenep. Data menunjukkan bahwa 47,507\% masyarakat di Kabupaten Sumenep masih belum mematuhi protokol kesehatan dilihat dari respon data InaRisk bahwa banyak dari keluarga dan desawisma yang belum menyediakan hand sainitizer, tempat cuci tangan, tidak menyediakan perlengkapan P3K, obat-obatan dan vitamin, sedangkan aktivitas keluarga di lingkungan masyarakat bergantung pada penghasilan harian yang mengharuskan tetap bekerja di luar rumah dan $97,737 \%$ masyarakat di Kabupaten Sumenep mengetahui tentang COVID-19.

\section{Ucapan Terima Kasih}

Ucapan terima kasih disampaikan kepada Universitas Wiraraja atas Hibah Pengabdian Kepada Masyarakat dengan Kontrak Hibah Pengabdian Kepada Masyarakat Dana Internal Nomor 002/SP2H/PKM-DI/LPPM/UNIJA/VI/2020

\section{Daftar Pustaka}

Amila, Hutajulu, Johansen.et.al. (2021). Penilaian Resiko Keluarga Terkait Covid-19 Menggunakan Aplikasi Assesment Keluarga InaRisk. Jurnal Ilmiah Keperawatan Imelda. http://jurnal.uimedan.ac.id/index.php/ JURNALKEPERAWATAN

Badan Nasional Penanggulangan Bencana. (2020). Panduan Penggunaan InaRisk. http://inarisk.bnbp.go.id.

Friedman, M. (2010). Keperawatan Keluarga. Buku Kedokteran.

Izzani, Ahmad Fadhil.et.al. (2020). Efektifitas Aplikasi InaRisk Personal Untuk Edukasi Siaga Covid-19 Di Kabupaten Temanggung. Laporan 
Santika, I. G. N. (2020). Optimalisasi Peran

Kuliah Kerja Nyata. Semarang: Universitas Negeri Semarang.

Oktowaty, S., Setiawati, E. P., \& Arisanti, N. (2018). Hubungan Fungsi Keluarga Dengan Kualitas Hidup Pasien

Penyakit Kronis Degeneratif di Fasilitas Kesehatan Tingkat Pertama. 4,6 .
Keluarga Dalam Menghadapi Persoalan Covid19: Sebuah Kajian Literatur. 6(2), 11. 